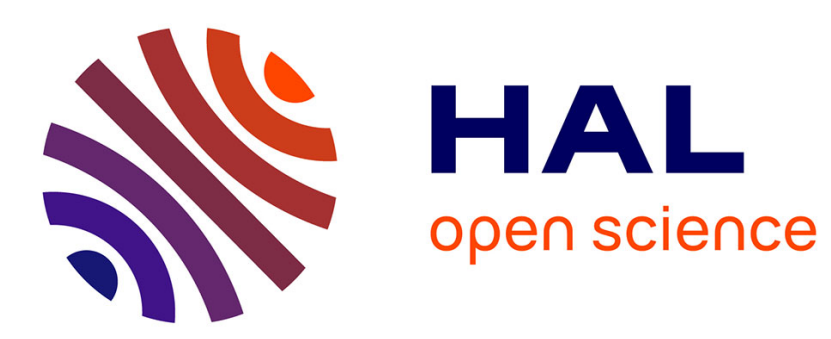

\title{
Recent expansion of Pinus nigra Arn. above the timberline in the central Apennines, Italy
}

\author{
Piermattei, Renzaglia, Urbinati
}

\section{To cite this version:}

Piermattei, Renzaglia, Urbinati. Recent expansion of Pinus nigra Arn. above the timberline in the central Apennines, Italy. Annals of Forest Science, 2012, 69 (4), pp.509-517. 10.1007/s13595-0120207-2 . hal-00930856

\section{HAL Id: hal-00930856 https://hal.science/hal-00930856}

Submitted on 1 Jan 2012

HAL is a multi-disciplinary open access archive for the deposit and dissemination of scientific research documents, whether they are published or not. The documents may come from teaching and research institutions in France or abroad, or from public or private research centers.
L'archive ouverte pluridisciplinaire HAL, est destinée au dépôt et à la diffusion de documents scientifiques de niveau recherche, publiés ou non, émanant des établissements d'enseignement et de recherche français ou étrangers, des laboratoires publics ou privés. 


\title{
Recent expansion of Pinus nigra Arn. above the timberline in the central Apennines, Italy
}

\author{
Alma Piermattei • Francesco Renzaglia • Carlo Urbinati
}

Received: 29 October 2011 / Accepted: 2 April 2012 /Published online: 8 May 2012

(C) INRA / Springer-Verlag France 2012

\begin{abstract}
- Context The altitude of timberlines in the central Apennines has lowered over the past few thousand years due to interacting natural and anthropogenic disturbances. These timberlines are usually sharp and consist of coppiced beech forests.

- Aims We found scattered individuals of European black pine (Pinus nigra Arn.) at two high elevation sites above the timberline on limestone slopes. We investigated the spatial and temporal pattern expansion of black pine and assessed vigour and growth dynamics of pine trees.

- Methods Over 250 individuals were mapped in the two sites using GPS. Several site and tree parameters were measured. Tree-ring widths and the frequency of intraannual density fluctuations were also recorded.

- Results Black pine expansion started around 30 years ago. Pine trees are randomly distributed at higher elevations with no visible spatial pattern. Germination peaks were synchronous in the two sites, and tree growth displayed very similar chronologies, with synchronous occurrence of intra-annual density fluctuations.

- Conclusion We hypothesise that the reduced livestock grazing over the last decades as well as climate warming are the major driving forces behind the high-altitude expansion of
\end{abstract}

\section{Handling Editor: Eric Rigolot}

Contribution of the co-authors Alma Piermattei has collected most of the field data, run most of the analyses, wrote the first draft of the manuscript and organized the revision editing.

Francesco Renzaglia provided the cartographic layout (GIS based) and designed the geostatistical analysis.

Carlo Urbinati has designed the experiment, collected some of the data, supervised the work, wrote the final draft and final revision editing.

A. Piermattei $\cdot$ F. Renzaglia $\cdot$ C. Urbinati $(\bowtie)$

Department of Agricultural, Food and Environmental Sciences,

Università Politecnica delle Marche,

60131 Ancona, Italy

e-mail: c.urbinati@univpm.it black pine on the central Apennines, where this species was present in pre-historic times.

Keywords European black pine $\cdot$ Treeline ecotone $\cdot$ Climatic change $\cdot$ Livestock grazing $\cdot$ Tree growth $\cdot$ IADF

\section{Introduction}

In the last few decades, climate and land use changes have triggered treeline ecotone dynamics both at high latitude and altitude in several areas of the planet; however, not all have shown evidence of timberline advancement (Holtmeier and Broll 2005, 2007; Harsch et al. 2009; Harsch and Bader 2011). Where forest tree recruitment has occurred on tundra or alpine grasslands the structure and function of these ecotones are changing. However, modelling spatial and temporal patterns of these successional processes is complex, due to the numerous driving and adverse factors involved (Holtmeier and Broll 2007). On a worldwide scale, treeline shifts can generally be described as climate driven (Grace et al. 2002; Parmesan and Yohe 2003; Körner and Paulsen 2004), but this is less true at regional scale, in local areas subject to the inter-related influence of both geomorphic and anthropogenic factors (Cairns and Moen 2004; Butler et al. 2007) such as most temperate European mountain regions (Dirnböck et al. 2003; Camarero and Gutierrez 2004; Beniston 2005). Climate warming can favour germination and growing conditions in these areas, but local topography, soil and human interference may reduce the forest expansion (Gehrig-Fasel et al. 2007; Speed et al. 2010).

In Italy, most studies of treeline dynamics have been conducted in Alpine environments (Motta and Nola 2001; Carrer and Urbinati 2001; Carrer and Urbinati 2004; Colombaroli et al. 2010; Leonelli et al. 2011) due to the higher mountains, prevalence of conifers and less human disturbance. The major finding has been that Larix decidua and Pinus cembra forests 
have shifted upwards, but it is not yet known whether and to what degree this is a result of pasture abandonment or due to climate warming (Motta and Nola 2001; Motta and Lingua 2005).

Very few studies have been carried out in the Apennines, the second most important mountain range in Italy $(1,300 \mathrm{~km}$ along a NW-SE direction), where a combination of natural and anthropogenic disturbances over the last millennia have altered forest cover and the treeline. The more oceanic climate and the stronger influence of winds together with human activities have reduced the altitudinal limit of the timberline to a current maximum of 1,800-1,900 ma.s.l. in the central-northern Apennines and 2,000-2,100 $\mathrm{m}$ in the most southerly part. During the Holocene Climatic Optimum (HCO), these timberlines were estimated as being $150 \mathrm{~m}$ higher (Ravazzi and Aceti 2004).

Species composition also varies. Timberlines in the northern and central Apennines are mostly formed by European beech (Fagus sylvatica) and are often the result of ancient forest removal to obtain grasslands used initially for wildlife hunting and later for livestock grazing (Pezzi et al. 2007; Pezzi et al. 2008; Gallucci et al. 2010). Only at rare locations (i.e., Majella) mountain pine (Pinus mugo Turra) dwarf shrublands dominate the highest plateaux up to 2,450 ma.s.l. (Stanisci et al. 2005). Timberlines in the southern Apennines are mainly composed of two species of the Mediterranean orobiome: Pinus leucodermis at Mt. Pollino and Pinus nigra subsp. laricio, together with the endemic Betula aetnensis, in Sicily.

In the past few decades some high altitudinal grasslands of the central Apennines have been colonised by shrub species (i.e., Juniperus spp., Rhamnus spp., Genista spp., Rosa spp.) and, less frequently, tree species (Pinus spp., Sorbus aria, and rarely F. sylvatica) (Stanisci et al. 2005; Gallucci et al. 2010). On the limestone slopes of two of the major peaks in the central Apennines, between Marche and Umbria, we found scattered individuals of European black pine (P. nigra Arnold) above the forest limit. This species was commonly planted at lower altitudes during the twentieth century for slope erosion protection. P. nigra is a highly polymorphic and complex taxon, widespread in the mountain areas of the Mediterranean basin. Its optimal distribution is between 800 and 1,500 ma.s.l. (Isajev et al. 2004). The "Flora Europaea" (Jalas and Suominen 1989) reports two indigenous subspecies for Italy: P. nigra subsp. laricio (Poiret), in Calabria and Sicily (from 900 to 2,000 ma.s.1.), and P. nigra subsp. nigra on a few karst sites of the eastern Alps (var. austriaca) and on limestone soils of the central Apennines (var. italica) (Gellini 1968). No specific paleobotanical records are available for our treeline ecotones, but pollen records from sites relatively nearby like Campotosto lake (1,300 ma.s.1.) (Coltorti et al. 1998) and Colfiorito swamp (700 ma.s.1.) (Brugiapaglia and De Beaulieu 1995) confirm a more widespread distribution of Pinus spp. in the central Apennines during the post-Würmian anathermic period. Some authors also hypothesized the former presence of open woodlands with conifers and prostrate junipers just above the timberline beech forest (Marchetti 1936; Stanisci 1997).

Although the two study sites are $150 \mathrm{~km}$ apart, they have different geomorphological traits and land use histories and they feature a very similar upslope tree expansion process. We attempted the reconstruction of its spatio-temporal dynamics and hypothesized that climate warming could be one of the factors involved in this advancement.

The scattered distribution of trees, characteristics of the black pine seeds and distance from the local sources indicate a wind-driven secondary seed dispersal. This involves a stepwise process where seeds are first scattered from the mother plant onto the ground from where they can again be lifted and moved several times by wind or air turbulence unless they deteriorate or are permanently entrapped (Johnson and Fryer 1992; Greene and Johnson 1997).

The objectives of our study were: (1) to investigate the spatial pattern of the species above the current timberline; (2) to date the time sequence of black pine recruitment; (3) to assess the vigour and growth patterns of pine trees and their level of adaptation to extreme microclimate conditions and (4) to discriminate the role of climate variability and pasture abandonment as possible major driving forces for this process of vegetation dynamics.

\section{Material and methods}

\subsection{Study sites}

The two study sites are the treeline ecotones of two major mountains in the central Apennines: Mt. Acuto $(1,668 \mathrm{~m}$ a.s.1.) and Mt. Vettore (2,476 ma.s.1.), both located in the Marche region, $150 \mathrm{~km}$ apart along a NW-SE direction (Table 1). There are no climate records for high-altitude sites in the area, so data were retrieved from the nearest weather stations: Monte Monaco $\left(987 \mathrm{~m}\right.$ a.s. $1 ; 42^{\circ} 53^{\prime} \mathrm{N}-13^{\circ}$ $\left.19^{\prime} \mathrm{E}\right)$ for Vettore and Fonte Avellana ( $689 \mathrm{~m}$ a.s. $1 ; 43^{\circ} 28^{\prime} \mathrm{N}-$ $12^{\circ} 40^{\prime} \mathrm{E}$ ) for Acuto. We used time series for the period 1961-1990: mean annual temperature is $11.1^{\circ} \mathrm{C}$ at Vettore and $11.6^{\circ} \mathrm{C}$ at Acuto; annual precipitation is 1,708 and $1,210 \mathrm{~mm}$, respectively, occurring mainly from autumn to early spring and with periods of drought in mid-summer. Snowfalls are more frequent between January and March, but permanence on the ground is limited and discontinuous. According to the Rivas-Martinez bioclimatic classification system both sites have a temperate oceanic macrobioclimate and a low supra-temperate bioclimate, but Vettore features an upper humid ombrotype and Acuto a low hyperhumid ombrotype (Rivas-Martinez and Rivas-Saenz 2009).

Carici humilis-Seslerieto apenninae grasslands, typical vegetation for high elevation limestone slopes, prevail in 
Table 1 Coordinates and main physiographic characteristics of the two study sites

\begin{tabular}{lll}
\hline & Vettore & Acuto \\
\hline Latitude & $42^{\circ} 49^{\prime} \mathrm{N}$ & $43^{\circ} 27^{\prime} \mathrm{N}$ \\
Longitude & $13^{\circ} 16^{\prime} \mathrm{E}$ & $12^{\circ} 42^{\prime} \mathrm{E}$ \\
Peak altitude & 2,476 ma.s.l. & 1,668 ma.s.l. \\
Aspect & $\mathrm{S}-\mathrm{SE}$ & $\mathrm{N}-\mathrm{NW}$ \\
Main bedrock type & limestone & limestone \\
Average slope & $65 \%$ & $45 \%$ \\
Timberline altitude & 1,600 ma.s.l. & $1,350-1,450$ ma.s.l. \\
Timberline forest & Black pine forest & Coppiced beech \\
type & (plantation) & forest \\
Area covered by survey & 120 ha & 50 ha \\
\hline
\end{tabular}

both areas; Seslerio nitidae-Brometum erecti grasslands are also found at Vettore. Livestock grazing on these grasslands has never been intensive. Cows and sheep are the most common pasturing animals in the Marche region, but their numbers have decreased markedly since 1960 due to the widespread abandonment of rural and mountain areas (ISTAT 2010). Other local data, when available, are not homogeneous and therefore not completely reliable for assessing the influence on natural vegetation dynamics. At Vettore, where the only livestock are sheep, pasturing is between June and October, up to 2,100 ma.s.1., and the livestock units (LSU) have decreased by about $50 \%$ over the last 40 years. At Acuto, the livestock has changed over the same period: until 1970 it was composed almost entirely by sheep, but these were gradually replaced by cows and horses and finally disappeared in the 1990s. LSU could not be computed at this site. Grazing is generally permitted 150 days/year between the end of May and mid-October.

At Acuto, scattered small pine trees grow above the current timberline, formed by the upper limit of a coppiced beech forest, ranging between 1,300-1,400 ma.s.l. The only possible seed source is a residual plantation of $P$. nigra (less than 100 trees left), located on the same slope at about 300 ma.s.l. below the treeline. Diachronic remote imagery highlights that the beech timberline has not advanced in the last 60 years (Gallucci et al. 2010), as also observed along a transect in the northern Apennines (Pezzi et al. 2007). At Vettore, the timberline is around 1,600 ma.s.l., formed mainly by an extensive mixed coniferous forest planted between 1940 and 1960 to control slope erosion and also by small residual patches of the original beech forest.

Aerial photographs proved useless for detecting young pine trees, due to the small size and shrub-like features of most individuals. Analyses were done at Acuto in 2005 and 2006 from the timberline to the mountain top; at Vettore between 2007 and 2009 from the timberline up to the last pine, found at about 2,100 ma.s.1..

\subsection{Measured parameters and analysis}

The analysis included only individuals growing above the timberline: a total of 253 pine trees were found, 72 at Acuto (in an area of about 50 ha) and 181 at Vettore (120 ha). We recorded or measured the following parameters for each specimen: (1) geographic coordinates and elevation using a GPS, (2) aspect, (3) type of microhabitat (bare rock, rock debris, grassland or shrubland), (4) habitus (tree or shrub physiognomy), (5) social status (single tree or in a group), (6) tree vigour (according to five classes based on stem and crown damage: 1 , no damage; 2 , minor damage; 3 , medium damage; 4, major damage; 5, dead), (7) basal stem diameter, (8) total tree height, (9) crown depth, (10) annual height increment (length of stem internodes) and (11) needle age. For age determination and tree-ring analysis we also extracted one core with a Pressler borer from all individuals having a basal stem diameter $\geq 4 \mathrm{~cm}$.

All the cores were mounted on wooden supports and thoroughly polished with progressively finer sandpaper. Tree-ring width measurement, at $0.01 \mathrm{~mm}$ accuracy, was provided by the semi-automatic LINTAB system and WinTSAP (Rinntech). We measured a total of 224 cores, 156 from Vettore and 68 from Acuto. The radial and vertical annual increment series could not be cross-dated due to the high individual variability caused by the young age and isolated growth of the trees.

We recorded any intra-annual density fluctuations (IADF) in the single tree-ring series from the two sites. IADF are considered to be tree-ring anomalies or false rings (Wimmer 2002) and appear after a significant alteration of cambial activity when unusual conditions interrupt normal radial growth, producing latewood-type cells in the earlywood or earlywood-type cells in the latewood (Fritts 1976). IADF are mainly climate driven and are useful indicators of tree adaptation to changing environmental conditions. We computed their annual frequency rate for each site and built a discontinuous time series of IADF occurrence. By means of correlation analysis, we also tested their possible relationships with tree altitude, cambial age and some annual climatic variables (temperature, precipitation and estimated water deficit).

Due to incomplete local climate time series we used spatially gridded $\left(1^{\circ} \times 1^{\circ}\right.$ of latitude and longitude) mean monthly temperatures and precipitation for the period 19212006 (CRU, University of Anglia, www.cru.uea.ac.uk/cru/ data). By means of the Bioclimatic software (Rivas Martinez and Rivas Saenz, 2009; www.globalbioclimatics.org), we estimated the water deficit at the two sites and tested mean changes within 30-year lags (1921-1950, 1951-1980 and 1981-2006). For the period 1980-2006, we also checked the correlations between annual water deficit and IADF occurrence, germination frequency, mean radial and height annual increments. The software STATISTICA was used for univariate statistical analyses. 
To characterize the tree spatial pattern within the study sites, point pattern analysis techniques were applied by means of Ripley's K (Ripley 1977) and the O-ring functions (Wiegand et al. 1998) using the PROGRAMITA software (Wiegand and Moloney 2004).

\section{Results}

\subsection{Spatio-temporal distribution}

The timberline altitudes are different at the two sites, but the pine expansion seems to be favoured at higher locations: $60 \%$ of the individuals are above 1,500 ma.s.l. at Acuto (max. 1,653 ma.s.1.) while $85 \%$ of those at Vettore are between 1,700 and 2,046 ma.s.l. (Fig. 1). Negative trends between tree age and elevation at both sites indicate a progressive ascent of the pine trees, even if the relationship is only significant for Vettore $(r=-0.31, p \leq 0.05)$ (Fig. 2). The spatial pattern analysis did not reveal any clumped distribution of pine trees and confirmed the null hypothesis of their random dispersal above the current timberline at both sites (Fig. 3a, b).

The cambial age frequency distribution reveals that the pine recruitment started more than 10 years earlier and decreased a few years later at Vettore, whereas at Acuto the process had a shorter duration and more abrupt features. However periods of higher germination rates are synchronous at the two sites: 1991-2001 at Vettore and 1992-1999 at Acuto (Fig. 4). Both have Gaussian trends typical of even-aged populations.

\subsection{Growth performance}

At both sites, pine germination is favoured on dry grasslands and in cracks on bare rock with scarce vegetation cover. Most of the trees, due to their extreme locations, have been exposed

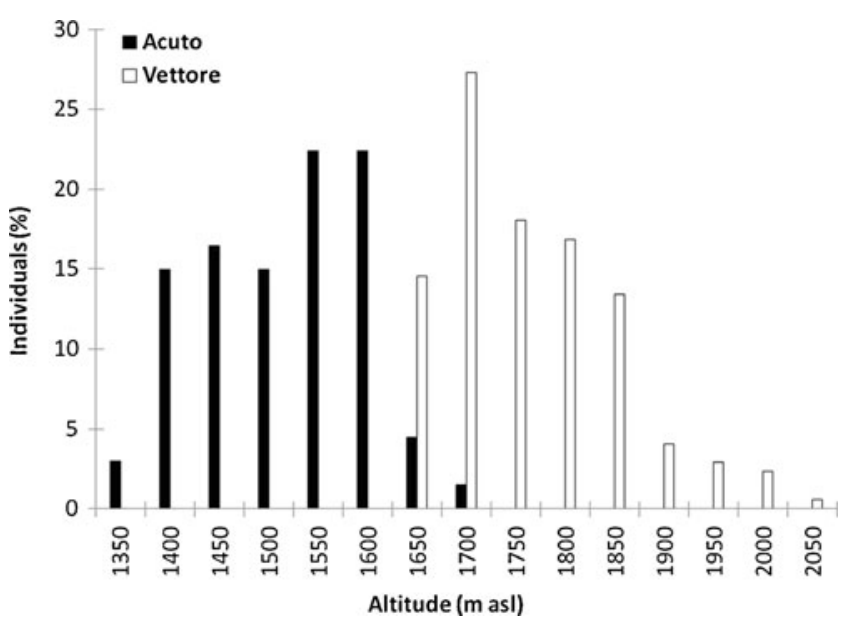

Fig. 1 Frequency distribution of the sampled pine trees at the two study sites, according to their altitudinal location

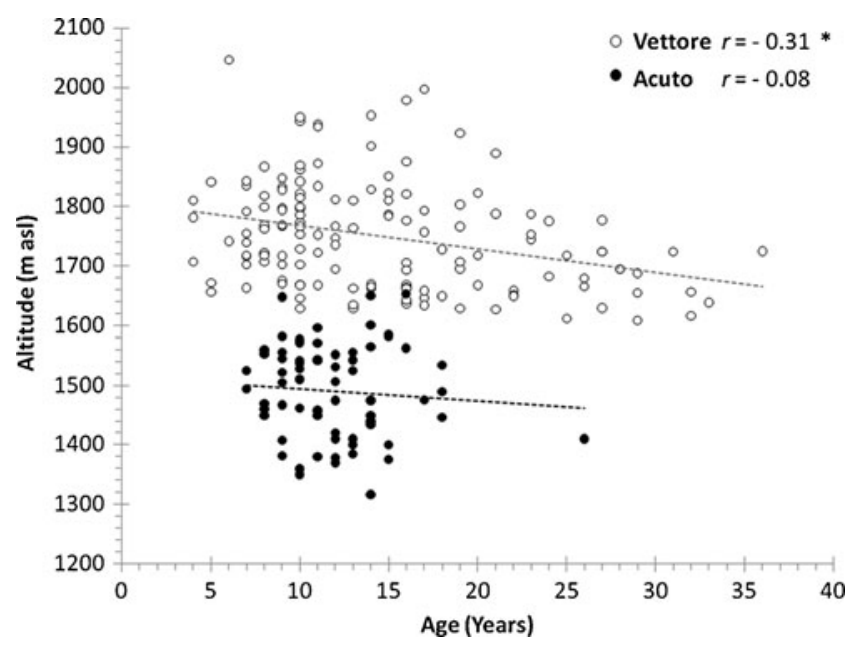

Fig. 2 Correlation between elevation and cambial age of pine trees $(* p \leq 0.05$ significance level)

to one or more disturbance factors (i.e., rock and debris fall, wind, snow and animal bark stripping); nonetheless, only a
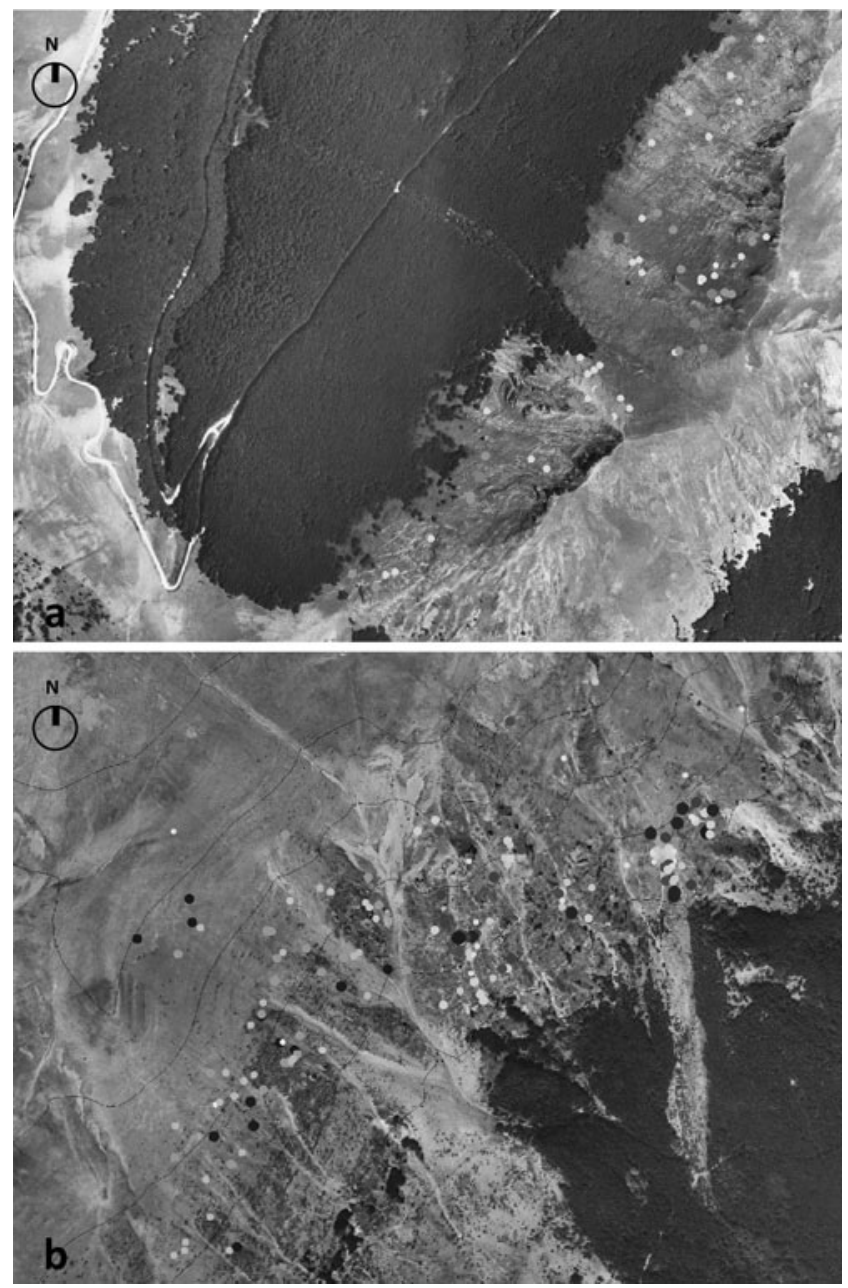

Fig. 3 Spatial distribution of sampled individuals beyond the current timberline: a Acuto; b Vettore. Circles coloured from white to black indicate increasing tree age within 5-year classes ( $0-5$ to $30-35$ years) 


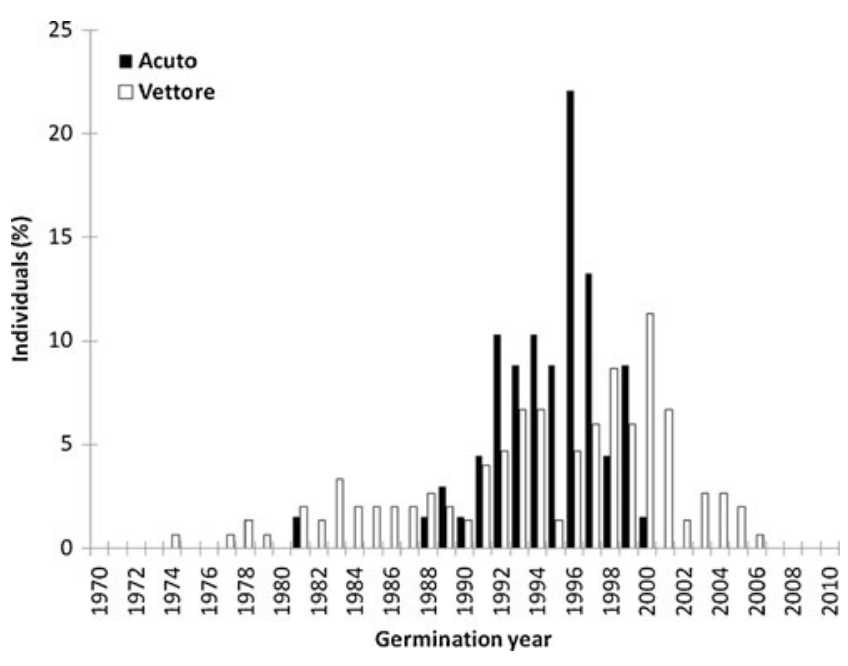

Fig. 4 Frequency distribution of sampled individuals according to their cambial age. Age was estimated from cores extracted at the lowest possible height at the stem base of pine trees having diameter $>4 \mathrm{~cm}$ (156 cores extracted at Vettore and 68 at Acuto)

few trees were dead (3\% Acuto and $2 \%$ Vettore) or with major damage that could compromise survival $(10 \%$ Acuto and $6 \%$ Vettore). A remarkable proportion of the trees are damage free (28\% Acuto and $22 \%$ Vettore), while the majority show minor or medium damage (59\% Acuto and $70 \%$ Vettore).

We used stem basal diameter, tree height and cambial age to assess the functional relationships of growth performance. Mean diameter is $9 \mathrm{~cm}(0.6-35 \mathrm{~cm})$ at Vettore and $6 \mathrm{~cm}(2-14 \mathrm{~cm})$ at Acuto; mean height is $150 \mathrm{~cm}$ $(12-750 \mathrm{~cm})$ at Vettore and $94 \mathrm{~cm}(28-215 \mathrm{~cm})$ at Acuto. The tree diameter-height correlation is positive and significant ( $p \leq 0.05$ at both sites: $r 0.95$ at Vettore and $r 0.83$ at Acuto). Age-height and age-diameter correlations are also positive and significant, but lower than the diameter-height correlation at both sites (Fig. 5a-c). Most of the trees at Acuto and a consistent part at Vettore fall within the threshold of $13 \mathrm{~cm}$ in stem diameter, $200 \mathrm{~cm}$ in tree height and 18 years of cambial age and could share the same linear regression function (Fig. 5, shaded area).

Vertical and radial annual increments averaged for all individuals show higher values and deviations at Vettore, especially for height growth. However these two variables are positively and significantly correlated, revealing that annual growth of pines, at either site, is homogeneously calibrated in both directions and scarcely influenced by other variables (Fig. 6).

\subsection{Tree rings and climate}

\subsubsection{Distribution of intra-annual density fluctuations}

All IADF are present as earlywood-type cells in the latewood band, near the ring edges, revealing that cambial activity was first reduced or stopped during late summer
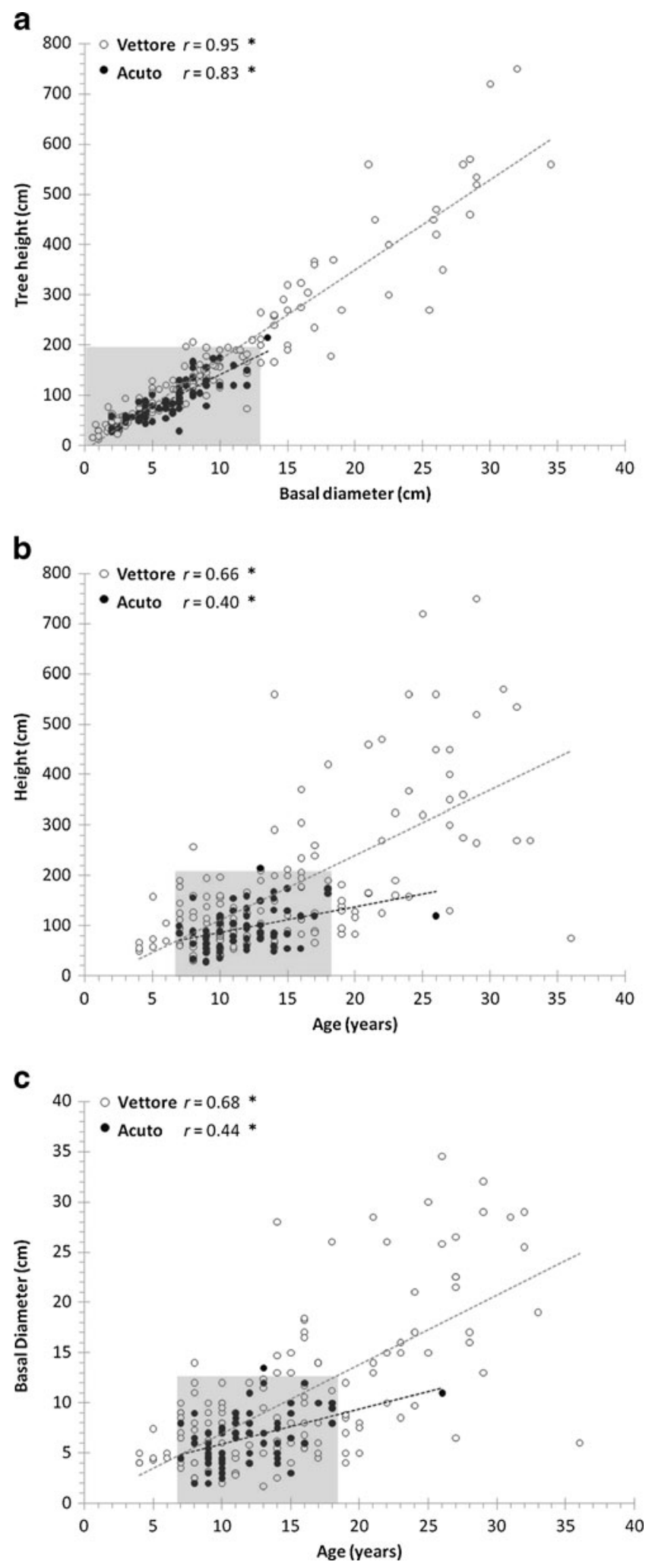

Fig. 5 Correlation between the main tree growth features of all individuals from the two sites ( ${ }^{*} p \leq 0.05$ significance level); a stem basal diameter and total height; $\mathbf{b}$ total height and cambial age; $\mathbf{c}$ stem basal diameter and cambial age. The grey-shaded area highlights the most fitted values 


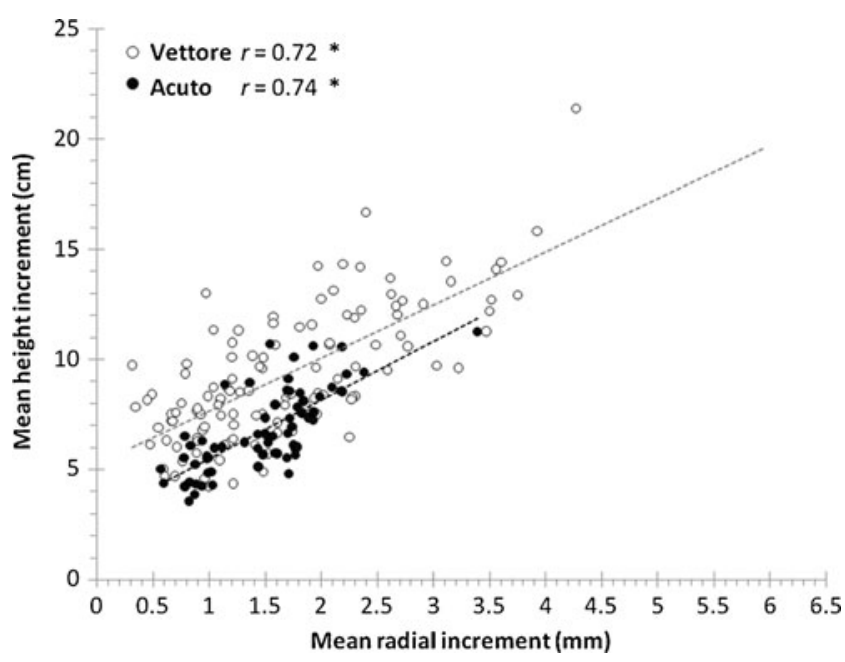

Fig. 6 Correlation between mean longitudinal (annual stem elongation) and radial (tree-ring width) increments of individual trees at the two sites $\left({ }^{*} p \leq 0.05\right.$ significance level)

droughts (August to mid-September) and recovered during late summer and early autumn. IADF annual frequency is computed as the percentage of number of trees with IADF of all the individuals present each year and it varies with sample depth (Fig. 7). The distribution is bimodal at Vettore, with a first wave between 1980 and 1989 and major peaks in 1984 and 1988 ( $>30 \%$ of the running total) and a second wave between 1992 and 2007 with a minor peak in 1996 (less than $15 \%$ of the trees) and a maximum peak in 2003 (over $35 \%$ of frequency), one of the warmest and driest years in the last thousand years. At Acuto, where pines are younger, only one IADF wave occurred between 1994 and 2006. The frequency rates are higher, with major peaks in 1994-1995 (around $20 \%$ ), 2002-2003, and especially in 2004 when more than $40 \%$ of trees showed wood density fluctuations. Apart from these differences, the two trends are very similar, especially after 1995 when the total number of

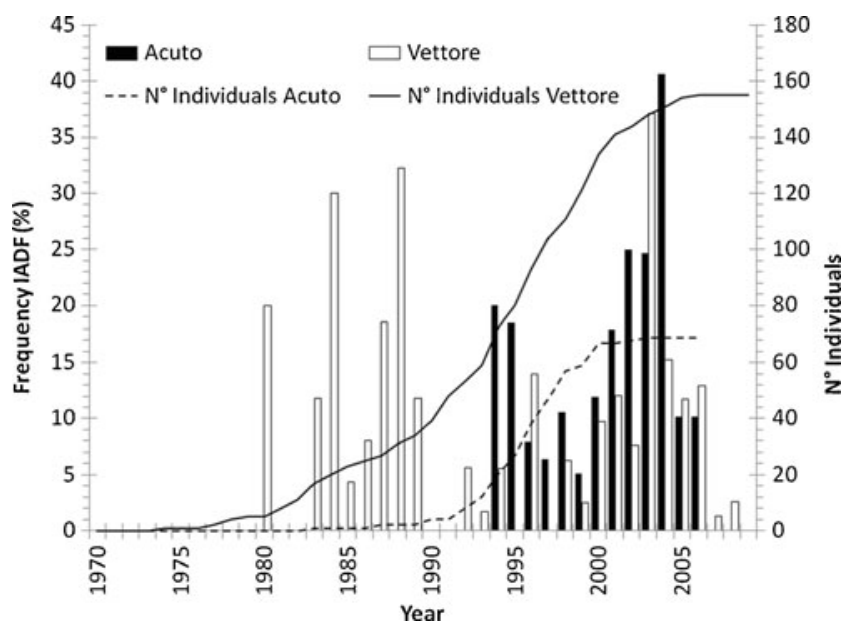

Fig. 7 Frequency distribution of intra-annual density fluctuations (IADFs) (left y-axis) and sample depth (right y-axis) samples is more robust. IADF are not correlated with tree altitude or cambial age and positively only with water deficit at Vettore $(r=0.51 ; p<0.05)$.

\section{Discussion}

Re-colonisation by $P$. nigra is a relatively common process near plantations at intermediate altitudes $(1,000-1,400 \mathrm{~m}$ a.s.l.) in the central Apennines, favoured by the wide ecological amplitude of the species and the decreasing grazing pressure over the last 40 years. However since this expansion takes place at higher altitudes (from 1,500-1,600 ma.s.l. up to $2,000 \mathrm{~m}$ ), above the current timberline, and shows synchronic features at both sites, we raised the question about the possible influence of climatic factors. This process is not linear, but the result of the synergy of various factors such as mast years, seed dispersion, germination efficiency and suitable site conditions fostering tree growth and eventually reproduction.

Wind-blown pine seeds have reached slopes at high elevation, where vegetation cover is lower, human and livestock disturbances reduced and climate conditions limiting (Fig. 2). Bare rocky sites or dry grasslands seem to be the most suitable habitat for black pine germination. The pine spatial distribution reveals random spatial patterns at both sites, seemingly caused by wind and secondary seed dispersion. Small rodents or some granivorous birds can feed on pine seeds, but they normally consume them near the food source. Unfortunately we do not have any information about mast years of local black pine; however, the literature reports them as being every 2-4 years (Isajev et al. 2004).

The canopy seed bank is particularly limited at Acuto due to the residual nature of the pine plantation and its greater distance from the germination sites. Furthermore the pines here are at lower altitudes, but more exposed to unfavourable climate conditions due to the north facing aspect of the slope, leading to higher rates of dead and severely damaged trees. At Vettore, the pine forest is widely extended up to the current timberline providing a more continuous and larger seed supply, while the southern slope exposure guarantees less extreme climate conditions.

The pine seed germination and seedling establishment could also have been influenced by grazing type and intensity. Excluding wild ungulates that are not present at these sites, only goats can possibly cause browsing damage or death to pine seedlings, which are usually not attractive to domestic animals due to their high resin content. However there is no record of goat rearing in the area during the twentieth century. Instead sheep, cows and horses are all very selective feeders. Only horses, due to their higher mobility, can cause uprooting or other mechanical damage to seedlings, but their presence is limited at Acuto. The behaviour of local shepherds might be of interest: in some Alpine pastures with scattered European 
larch, $P$. cembra seedlings were removed manually because they were considered an invasive species (Carrer and Urbinati 2001). In our study sites, especially Vettore that is included in a National Park, personal interviews revealed that this practice was avoided also for fear of sanctions.

All the above-cited factors seem to have affected the chronological patterns of pine expansion, which is more evenly distributed over the last 30 years at Vettore and concentrated within a shorter time lag and with pulse-like features at Acuto. Nonetheless, the highest germination peaks at both sites occurred between 1995 and 2000 (Fig. 4). The increased temperatures recorded over the past few decades may have provided more suitable conditions for germination and survival of black pine cohorts at high altitude. An explanation for the decrease in germination rate, very sharp at Acuto in 2000 and progressive between 2002 and 2006 at Vettore, is more controversial. On the one hand, pines on rocky soils, at their very early stages, can frequently have plagiotropic stem growth that may limit their detection. Monitoring should be done every few years in order to allow seedlings to reach a suitable size for a survey. Other limiting factors for germination can be extreme winter conditions rather than summer drought stress to which pine seems to be quite resilient and, at Acuto, lower and discontinuous seed supply from mother trees. Indeed chronological variability can cause decade-long or even century-long lags in treeline dynamics, even in continuously favourable climatic conditions (Holtmeier and Broll 2007).

Concerning growth performance, there is more size variability at Vettore due to the older age of pioneer trees and the presence of natural shelters such as large rock boulders and small natural terraces where pines have become much bigger than most other individuals. However, these differences do not reduce the significance of intra-site cross correlations between age, diameter and height of the pine trees; $r$ values for the diameter-height relationships at both sites are particularly high especially within a certain interval (grey-shaded areas, Fig. 5a-c). The high correlations ( $r>$ 0.7 ) between radial and height increments reveal consistent and very similar growth dynamics at the two sites, regardless of the lower values recorded at Acuto due to more unfavourable site conditions (Fig. 6).

A dendroclimatic analysis on older individuals of $P$. nigra from the nearby closed forest at Vettore proved that their tree-ring growth is (1) positively correlated to increased precipitation, especially in July, and more surprisingly in October (because most tree rings have not yet completed their annual formation) and (2) less sensitive to temperatures with negative correlation only in May (Piermattei 2009). Drought-induced IADF occurrence (mid-late summer), their frequencies and higher peak in the 2000-2005 period are similar at both sites, suggesting a possible dependence of their occurrence on climate warming. However a significant positive correlation was obtained only with summer water deficit at Vettore
( $r=0.51 ; p<0.05$ for the period 1980-2006), where the sampled individuals have $\mathrm{S}$ aspect and higher mean age.

IADF formation could be interpreted as an adaptive strategy to mid-late summer drought, especially at Acuto, where no significant relationships exist between mean tree-ring widths and IADF frequency even in the driest or warmest years (i.e., 2003). Several studies have shown that increased water deficit is the most probable cause of forest growth decline, although climate-growth relationships are unstable over time (Martin-Benito et al. 2010). P. nigra is in fact considered a reliable species for testing the effects of climate change on tree growth due to its intermediate altitudinal distribution (Andreu et al. 2007).

Nonetheless, these minor differences do not conceal the relevant similarities of the re-colonisation process at the two sites: (1) the trend and synchronicity of the pine recruitment, (2) the tendency to occupy higher altitudes and (3) the common growth patterns of a large proportion of the pine trees.

\section{Conclusion}

The expansion of $P$. nigra at high elevation on two sites of the central Apennines is not a straightforward process, but a complex one controlled by synergic factors like mast years, seed dispersion and germination efficiency. Anthropogenic factors, such as decreased livestock grazing and increased black pine seed availability (from previous plantations at lower elevation) can also play an important role. However, given the different site characteristics and the grazing histories of the two study sites, the similar spatio-temporal patterns of pine expansion supports the contribution of other factors such as climate. The temperature increase recorded in this area during the past 30-40 years could have triggered the process and provided more suitable conditions at high elevation for germination, survival, growth and eventually reproduction of these new black pine cohorts. At present, only the population at Vettore can potentially enhance its expansion, since some of the larger and older individuals located on safer sites have produced cones, creating the conditions for a more efficient seed dispersion at higher elevation.

Nonetheless, it is too early to regard this recent recruitment of pine trees as a timberline advancement, but we can probably envisage it as a rearrangement of the upper treeline ecotone, where this species had a more important role in pre-historic times. Our results confirm the complexity of timberline dynamics, especially where the influence of geomorphology, climate and topography is blended with that of human disturbance, making the disentangling of their individual roles very difficult. The programmed increase of study sites in other areas of the central Apennines and the 
monitoring of the existing ones should help to clarify the situation.

Acknowledgments We wish to thank the Monti Sibillini National Park for sampling authorization, Andrea Cola, Simone Cingolani and the TreeringLab staff for field and laboratory assistance. We are also thankful to Dr. Paride D'Ottavio (UNIVPM) and the "Azienda Speciale del Catria" for information on livestock and pasture management; to Patricia Crotty and Alison Garside for English text revision and two anonymous referees for helpful comments. The study was partially financed by the UNIVPM "Ateneo" Research project no. 4524/2009 (Spatio-temporal dynamics of forest vegetation and climate change in the Marche region).

\section{References}

Andreu L, Gutierrez E, Macias M, Ribas M, Bosch O, Camarero JJ (2007) Climate increases regional tree-growth variability in Iberian pine forests. Glob Chang Biol 13:1-12

Beniston M (2005) Mountain climates and climatic change: an overview of processes focusing on the European Alps. Pure Appl Geophys $162: 1587-1606$

Brugiapaglia E, De Beaulieu JL (1995) Late-glacial and holocene vegetation dynamics in central Italy: swamp of Colfiorito, Umbria. C R Acad Sci II Sci Terre Planets 321:617-622

Butler DR, Malanson GP, Fagre DB (2007) Influences of geomorphology and geology on alpine treeline in the American West-More important than climatic influences? Phys Geogr 28:434-450

Cairns M, Moen J (2004) Herbivory influences tree lines. J Ecol 92:1019-1024

Camarero JJ, Gutierrez E (2004) Pace and pattern of recent treeline dynamics: response of ecotones to climatic variability in the Spanish Pyrenees. Clim Chang 63:181-200

Carrer M, Urbinati C (2001) Spatial analyses of structural and tree-ring related parameters in a timberline forest of Italian Alps. J Veg Sci 12:643-652

Carrer M, Urbinati C (2004) Age-dependent tree ring growth responses to climate of Larix decidua and Pinus cembra in the Italian Alps. Ecology 85:730-740

Colombaroli D, Henne PD, Kaltenrieder P, Gobet E, Tinner W (2010) Species responses to fire, climate and human impact at treeline in the Alps as evidenced by palaeoenvironmental records and a dynamic simulation model. J Ecol 98:1346-1357

Coltorti M, Albianelli A, Bertini A, Ficcarelli G, Laurenzi MA, Napoleone G, Torre D (1998) The colle Curti mammal site in the Colfiorito area (Umbria-Marche Apennine, Italy): geomorphology, stratigraphy, paleomagnetism and palynology. Quat Int 47-48:107-116

Dirnböck T, Dullinger S, Grabherr G (2003) A regional impact assessment of climate and land-use change on alpine vegetation. J Biogeogr 30:401-417

Fritts HC (1976) Tree rings and climate. Academic, London

Gallucci V, Allegrezza M, Urbinati C (2010) Dinamismi spazio-temporali e sensitività climatica. Sherwood Foreste e Alberi Oggi 164:11-15

Gehrig-Fasel J, Guisan A, Zimmermann NE (2007) Tree line shifts in the Swiss Alps: climate change or land abandonment? J Veg Sci 18:571-582

Gellini R (1968) Posizione sistematica del Pino nero di Villetta Barrea in base ai caratteri anatomici degli aghi. Ann Accad Ital Sci For $17: 101-122$

Grace J, Berninger F, Nagy L (2002) Impacts of climate change on the tree line. Ann Bot (London) 90:537-544

Greene DF, Johnson EA (1997) Secondary dispersal of tree seeds on snow. J Ecol 5:329-340
Harsch MA, Hulme PE, McGlone MS, Duncan RP (2009) Are treelines advancing? A global meta-analysis of treeline response to climate warming. Ecol Lett 12:1040-1049

Harsch MA, Bader MY (2011) Treeline form a potential key to understanding treeline dynamics. Glob Ecol Biogeogr 20:582-596

Holtmeier F, Broll G (2005) Sensitivity and response of northern hemisphere altitudinal and polar treelines to environmental change at landscape and local scales. Glob Ecol Biogeogr 14:395-410

Holtmeier F, Broll G (2007) Treeline advance-driving processes and adverse factors. Landsc Online 1:1-33

Isajev V, Fady B, Semerci H, Andonovski V (2004) EUFORGEN Technical guidelines for genetic conservation and use for European black pine (Pinus nigra). International Plant Genetic Resources Institute, Rome (Italy), p 6

ISTAT (2010) Censimento Generale dell'Agricoltura, Istituto Nazionale di Statistica (www.censimentoagricolotura.istat.it). Accessed 18 Oct 2011

Jalas J, Suominen J (eds) (1989) Atlas Flora Europaea-distribution of vascular plants in Europe. Cambridge University Press, Cambridge

Johnson EA, Fryer GI (1992) Physical characterization of seed microsites - movement on the ground. J Ecol 80:823-836

Körner C, Paulsen J (2004) A world-wide study of high altitude treeline temperatures. J Biogeogr 31:713-732

Leonelli G, Pelfini M, Morra di Cella U, Garavaglia V (2011) Climate warming and the recent treeline shift in the European Alps: the role of geomorphological factors in high-altitude sites. Ambio 40:264-273

Marchetti M (1936) Ricerche sulla vegetazione dell'Etruria marittima VI-Analisi pollinica della torbiera di Campotosto (Appennino abruzzese). Nuovo G Bot Ital 43:831-871

Martin-Benito D, Del Rio M, Canellas I (2010) Black pine (Pinus nigra Arn.) growth divergence along a latitudinal gradient in Western Mediterranean mountains. Ann For Sci 67:401. doi:10.1051/forest/ 2009121

Motta R, Lingua E (2005) Human impact on size, age, and spatial structure in a mixed European larch and Swiss stone pine forest in the Western Italian Alps. Can J For Res 35:1809-1820

Motta R, Nola P (2001) Growth trends and dynamics in sub-alpine forest stands in the Varaita Valley (Piedmont, Italy) and their relationships with human activities and global change. J Veg Sci 12:219-230

Parmesan C, Yohe G (2003) A globally coherent fingerprint of climate change impacts across natural systems. Nature 421:37-42

Pezzi G, Bitelli G, Ferrari C, Girelli VA, Gusella L, Masi S, Mognol A (2007) Pattern temporale del limite altitudinale dei boschi di faggio nell'Appennino settentrionale. Un'analisi di dati fotogrammetrici. Forest 4:79-87

Pezzi G, Ferrari C, Corazza M (2008) The altitudinal limit of beech woods in the northern Apennines (Italy): its spatial pattern and some thermal inferences. Folia Geobot 43:447-459

Piermattei A (2009) Diffusione e dinamica di accrescimento di Pinus nigra A. sopra il limite superiore del bosco al Monte Vettore (AP). Università Politecnica delle Marche, Ancona

Ravazzi C, Aceti A (2004) The timberline and treeline ecocline altitude during the Holocene Climatic Optimum in the Italian Alps and the Apennines. In: Antonioli F and Vai GB (eds), Climex Maps Italy, Explanatory notes: $21-22$

Rivas-Martinez S, Rivas-Saenz S (2009) Worldwide Bioclimatic Classification System, 1996-2009, Phytosociological Research Center, Spain http://www.globalbioclimatics.org. Accessed 13 Oct 2011

Ripley BD (1977) Modelling spatial patterns (with discussion). J Roy Stat Soc B 39:172-212

Speed JDM, Austrheim G, Hester AJ, Mysterud A (2010) Experimental evidence for herbivore limitation of the treeline. Ecology 91:3414 3420 
Stanisci A (1997) Gli arbusteti altomontani dell'Appennino centrale e meridionale. Fitosociologia 34:3-46

Stanisci A, Pelino G, Blasi C (2005) Vascular plant diversity and climate change in the alpine belt of the Central Apennines (Italy). Biodivers Conserv 14:1301-1318

Wiegand T, Moloney KA (2004) Rings, circles, and null-models for point pattern analysis in ecology. Oikos 104:209-229
Wiegand T, Moloney KA, Milton SJ (1998) Population dynamics, disturbance, and pattern evolution: identifying the fundamental scales of organization in a model ecosystem. Am Nat 152:321337

Wimmer R (2002) Wood anatomical features in tree-rings as indicators of environmental change. Dendrochronologia 20:21-36 